\title{
Reading the Royal Entry (1604) in/as Print
}

\begin{abstract}
King James I's March 1604 entry into London, many recognize, departs from previous royal entry pageants through its use of triumphal arches, employment of professional dramatists, and emphasis on dialogue. But the 1604 entry also was notable for its essential print identity. Print records of royal entries were common by the time of Elizabeth's accession, and the 1559 text commemorated the event mainly for the queen and court, listing no author. By contrast, James's entry, staged and performed over one day, generated four different printed texts, each with a declared author or authors. This article considers how all four entry texts together produce a highly contested portrait of ideas about print, authorship, and authority at the outset of the Jacobean period.
\end{abstract}

Oxford's monumental Thomas Middleton: The Complete Works, dense not only with plays but also with lord mayor's shows and essays on the spectacles they scripted, offers vivid evidence of new interest in early modern pageantry. Scholarly reassessments of long neglected public pageantry have newly considered the significance, in their own time and in ours, of such performances, including royal entries. ${ }^{1}$ As Richard Dutton has argued:

To ignore the civic pageants of the Tudor and Stuart period is to ignore the one form of drama which we know must have been familiar to all the citizens of London, and thus an important key to our understanding of those times and of the place of dramatic spectacle in early modern negotiations of national, civic, and personal identity. $^{2}$

Dutton signals a critical investment that Tracey Hill further enunciates, arguing that we must assess early modern lord mayor's shows precisely for their public and complexly collaborative nature as spectacles. Hill particularly argues that civic

Heather C. Easterling (easterling@gonzaga.edu) is an associate professor in the department of English at Gonzaga University. 
pageantry is not 'exclusively literary', and that, 'we must try to lose the writercentric view that the printed text is the most important part of [pageantry]'. ${ }^{3}$

The Oxford Middleton includes a pageant, however, that belies Hill's diminution of print as central to pageantry. This collected works volume attributes The Whole Royal and Magnificent Entertainment of King James through the City of London, 15 March 1604, with the Arch's of Triumph not only to Middleton, but also to 'Thomas Dekker, Stephen Harrison, Ben Jonson, and Thomas Middleton'. ${ }^{4}$ Such a list suggests collaboration, but, I argue, this is a list of rivals rather than partners. King James I's ceremonious London entry in March 1604, staged and performed over a single day, swiftly was rendered into four different printed texts: quartos from Jonson and Dekker; Stephen Harrison's elaborate folio text of engravings and speeches, The Arch's of Triumph; and Gilbert Dugdale's apparent eyewitness account, The Time Triumphant. ${ }^{5}$ Scholars and critics have noticed this range of printed works, but attention has focused on the texts' ability to render a 'complete' picture of the day, or on Jonson's and Dekker's quartos as part of broader studies of each author. ${ }^{6}$ Modern critics, meanwhile, have too easily granted the orthodoxy of these texts; for example, Graham Parry elides texts with event in describing the entry as 'Combining architecture with emblem, tableau, drama and music ... the arts served the monarchy by projecting a state mythology'7 But Parry's assessment confuses the event's aspirations with its actual unfolding and is particularly complicated by the implied contests and ambitions of the entry in and as print. The new collected works edition lists Middleton as an equal author, but the text credits him with a single speech, that of Zeal, in Dekker's final pageant in the event. ${ }^{8}$ Such a listing as equal author, as well as this Complete Works's inclusion of a sixtypage pageant text to which Middleton contributed one speech, vividly signals an editorial and critical turn towards pageantry as collaborative, not writer-centric, text. James I's entry into London was the most significant pageant of its time, so Middleton's connection to it is important. But the Middleton collection treats the pageant in ways that are both illuminating and obfuscating, provocatively eliding the royal entry's complex print identity.

Middleton editor Malcolm Smuts's authoritative introduction cautions that 'Readers should not approach The Whole Royal and Magnificent Entertainment... as a completely accurate description of the entry ... [for] it derives from three highly shaped texts', yet his edition shapes its presentation of a single text out of the actual diversity of printed texts noted above. ${ }^{9}$ More eliding of a complex print story comes with this edition's title, which sutures elements of titles from the different printed texts of 1604 to invent a composite title that never existed. ${ }^{10}$ As one of the most up to date and authoritative editions of the pageantry for 
James I, ${ }^{11}$ this collated text is invaluable, and I would hasten to point out Smuts's clear articulation of his text's aim of providing 'an ideal reconstruction.'. ${ }^{12}$ But I am interested in the range of texts behind this present day composition, and I begin with the Oxford Middleton because this edition neatly signals — in what it acknowledges and elides - the importance of reading this particular pageant in and as its numerous printed versions. This new composite edition precisely demonstrates the power of a printed text to shape, interpret, and revise an event, in 1604 and today.

Unlike pageantry scholars like Hill, my interest lies in the entry's printed texts, but my approach nevertheless is indebted to Hill's investment in the materiality of pageantry's spectacle and economics. Hill's interest in recovering the 'small, local meanings', the material aspects, and 'lived experience' of the lord mayor's shows, ${ }^{13}$ offers a model for reading the royal entry in and as print. Such a reading links one set of 'small local meanings' with another, as the royal entry texts connect pageantry with the material nuances of early modern print. Approaching early modern drama as a print phenomenon has a longer history that includes the work of bibliographers such as W.W. Greg and A.W. Pollard as well as more recent departures from new historicist preoccupations with performance. ${ }^{14}$ Lauren Shohet's investigation of courtly masques in print and Wendy Wall's nuanced attention to the political stakes and implications of the rise of print reveal that theatrical works in print did complex work. ${ }^{15}$ Shohet's attention to the fact that 'many masques enjoyed robust lives as print artifacts from the beginning of the seventeenth century' connects popular drama and other dramatic forms like the masque to the civic pageant: all were consistently encountered in print by the early seventeenth century, not simply in performance. 'Masque criticism has not fully acknowledged the masque's presence as a bi-medial form', explains Shohet, also warning against 'considering the masque uniquely as a performance form'. ${ }^{16}$

Wall's work further gestures to the importance of printed pageantry to revised studies of drama, print, and print culture. Observing the late sixteenth century as a moment when manuscript and print culture collide and a courtly ideal of literary amateurism and a new professionalism driven by an emerging marketplace intersect, she considers the 'formation of English Renaissance literary authority' by focusing on 'elements often neglected by scholarly accounts', including 'the complexity of the printed book commodity ... and the social construction of the print medium'. ${ }^{17}$ Wall analyzes the increasing authority and social and political significance of printed books to discuss not only popular plays but also Elizabeth I's 1558 royal entry pageant and Richard Mulcaster's printed book of it, published soon after as a record and commemoration. Elizabethan public spectacles, 
Wall argues, played out negotiations among queen, courtier, and audience about the terms of rule, but pageant-as-writing 'enacted another set of negotiations ... it becomes evident that [printed] accounts alter, contest, and reverse - rather than merely amplify - the political terms set up by the display event.' ${ }^{18}$ Wall's study points to the importance of reading the 1604 entry precisely in terms of its printed texts.

To this groundwork we can add Jonson scholar Joseph Loewenstein's recent monograph, The Author's Due: Printing and the Prehistory of Copyright. Printed books are literally material, but it nevertheless has been common among critics, Loewenstein argues, to abstract specific histories and significations into broad terms like 'book culture'. Loewenstein thus 'attempt[s] to account for the author', a project that means 'describ[ing] abstract transformations in terms of the practical transformations that produced them. ${ }^{19}$ Jonson is an essential figure in this highly material history of authorship and print culture, not just because of what his career might symbolize but because of what his specific literary interventions concretely shaped. Loewenstein writes, 'his writing and his behavior register crucial adjustments in the economic and cultural organization of intellectual property', including in the period of James I's accession. ${ }^{20}$

I reappraise the 1604 entry texts - collectively a competitive flurry and four individual expressions - as landmarks of this very process and history. While we can read the creation of multiple texts as evidence of the power of an event like a civic and royal cultural production, when brought together and read as material artifacts, the four reveal a decidedly less orthodox, highly contested climate involving the changing economics, technology, and rhetoric of print as well as emerging ideas of authorship and authority. Writing on Dekker's strategies for using print to 'mediate' pageant performances, David Bergeron observes the playwright conversing with his own text as a book as well as with books of past pageantry so that 'one book looks at another. ${ }^{21}$ I transpose this sense of selfconsciousness into the synchronic, competitive context of the 1604 texts. As they eye one another, they evince a moment when the significance of the market for printed texts, the market for printed drama, and the power of the printed text over the theatrical event all were in transition. While they scripted idealized spectacle, the multiple 1604 entry texts together record competition over control of production that is artistic and interpretive as well as commercial and material. 


\section{The Entry Texts}

All four texts rely on the event of James's royal entry, which finally occurred on 15 March 1604 after an eight-month delay due to plague in London. The king's progress followed a traditional route from the Tower of London to the city's western boundary of Temple Bar, interspersed with seven triumphal arches at key civic locations. ${ }^{22}$ Pageantry whose design and scripting had been awarded as commissions to Ben Jonson and Thomas Dekker accompanied each arch. Dekker and Jonson contributed 'devices' for three arches each, but Dekker had the larger commission, as he seems to have been charged with overseeing the entry's pageantry as a whole. His knowledge of two additional pageants presented by the Italian and Dutch merchants, reflected in his entry text, suggests that he may have been involved with these as well. Jonson took responsibility for the first and the last city pageants: the 'Londinium' arch at Fen-church Street, the 'Temple of Janus' arch at Temple Bar, and a final pageant in the Strand featuring two pyramids. Given their already contentious relationship as rival playwrights, ${ }^{23}$ Dekker's and Jonson's apparent collaboration on the entry not surprisingly yielded two different and distinctly competing quartos of the entry: from Jonson, B. Jon. His Part of the Magnificent Entertainment, and from Dekker, The Magnificent Entertainment. At stake with these two quartos is not simply artistic rivalry, however. Individually and together these works contest not just each other but the emerging idea of the author as well as the technology, authority, and practices of print. They also suggest a material rivalry between the stationers - publishers, printers, compositors - who licensed and produced these entry texts. I look at Jonson and Dekker's entry texts in two ways: as distinct authorial assertions and as notable expressions of the changing authority and practices of print in the period.

\section{Jonson}

A vivid feature of Jonson's quarto, as published just days after the entry in 1604, is the prominence of Jonson's name as author and of the book's provenance within London's print industry compared with the more minimal reference to the king and his entry as the occasion for this book:

B. JON:

HIS PART OF

King James his Royall and Magnifi-

cent Entertainement through his

Honorably Cittie of London, 
Thurfeday the 15 . of

March 1603.

So much as was presented in the fir $f \mathrm{t}$ and la $f \mathrm{t}$ of

Their Triumphall Arch's

With his $f$ peach made to the la $f$ t Prefentation, in the

Strand, erected by the inhabitants of the Dutchy,

and Weftminfter.

Al $f_{\mathrm{o}}$, a briefe Panegryre of his Maie $f$ ties fir $f \mathrm{t}$ and well

$\mathrm{Au} f$ picated entrance to his high Court of Parliament,

On Monday, the 19. of the fame

Moneth.

With other Additions.

Mart. Quando magis dignos licuit fpectare triumphos.

PRINTED AT LONDON BY V.S. FOR

EDWARD BLOUNT, $1604^{24}$

The pageantry on the day, partly authored by Jonson, may have centred on an elaborate rite with the king as its subject, but in the transition to Jonson's textual form the focus shifted to the author, the text more a monument to Jonson and to the printed book itself — and its author, printer, and publisher - than to the king or city. Julie Stone Peters has observed a growing sense of the authority of the text as a place where the author's intentions are 'unmutilated' by the stage in the seventeenth century. The text of a play did not simply bring a performance back to life but increasingly promised a presentation that was more complete and perfect. ${ }^{25}$ Peters makes these comments in reference to Beaumont and Fletcher's 1647 folio, a good four decades later than Jonson's 1604 quarto, so it is important to note how precociously Jonson expresses the same ideals. In offering to readers B. Jon. His Part of King James His Royal and Magnificent Entertainment, Jonson's aim is not to replicate the recent theatrical spectacle; his title summons those who wish to read Ben Jonson's art, not those looking for the complete event. Also pertinent is the fact that this quarto contains two other recent pageants written for the new king: the 'Panegyre' for James's first opening of Parliament and the 'Entertainment at Althorp' presented as James was making his way to London in 1603-4. The printed book is a poet's salvo, not a pageant souvenir.

Jonson's quarto also distances itself from the singular, ephemeral event of the entry in the presentation of the poet's three pageant scripts and in its textual apparatus. In the pages devoted to the 'devices' Jonson created, his text does not recreate pageantry but produces an entirely different event. While Jonson's text 
purports to monumentalize the royal entry, it chiefly monumentalizes itself — or perhaps we might describe it as the textualizing of every aspect of his pageantry, such that the event in an important sense becomes experienceable only as a printed text. The text's presentation of the pageant at Fenchurch Street, for example, begins with nearly seven pages devoted to describing the Londinium Arch on this site, carefully explicating the number of inscriptions on the arch, the names of figures or places, and the lengthy epigrammatic Latin passages. As James D. Mardock has observed, the 'arches are written texts' in Jonson's quarto. ${ }^{26}$ Jonson includes extensive, esoteric marginalia on every page and alongside every kind of detail, whether about the setting or an element of his pageant. The overall effect is of a singularly textual event: any live performance, by inevitably omitting this minute glossing, would be incomplete. His quarto strikingly offers readers much more understanding of and control over an event that, as bystanders on the day, they would have experienced either superficially or not at all. As one example, after seven pages of description of the Londinium Arch, Jonson describes how all was covered with a curtain of silk, 'painted like a thick cloud, and at the approach of the K[ing]. was instantly to be drawn'. ${ }^{27}$ If in performance this effect staged the king's powers of might and clarity, the page renders the reader — and also, of course, Jonson himself — as a more privileged and knowledgeable viewer and interpreter than even the king himself.

Such distancing from spectacle and emphasizing of author, text, and reader convey a frequently observed ambivalence in Jonson concerning popular success and his self-identified poet laureate ideals. A split emerges between spectacle and word, with the word seeming to be for Jonson often synonymous with the soul and with truth. Within two years, in prefatory remarks to the quarto edition of Hymenaei, Jonson would articulate this superiority of the word as truth and of print and the imprinted word over show: 'It is a noble and just advantage, that the things subjected to understanding have of those which are objected to sense, that the one sort are but momentary, and merely taking; the other impressing, and lasting: Else the glorie of these solemnities had perished like a blaze, and gone out, in the beholder's eyes. ${ }^{28}$ Jonson increasingly privileges not just word over image and art, but the printed word specifically. In the Hymanaei comment we also can recognize the distinctly Jonsonian concern for authorial control over text, so it should not be remarkable to find the same sensibilities and textual effects in the 1604 quarto. But in fact they appear in the entry quarto for the first time. Loewenstein - interested in Jonson's heavily annotated pages, which 'make possible a set of experiences obviously unavailable to performer or spectator' - points out that 'the conspicuously complicated Jonsonian page makes its 
first appearance in the Entertainments volume of 1604.29 Loewenstein elaborates on the impact of this technique:

[T] he annotations destabilize the format of Jonson's page, announcing, gravely insisting, that these are not scripts. The strange appearance of these texts is often overlooked. A certain amount of typographic chatter is common to many Renaissance texts... [but here] the dense play of roman and italic type (sometimes further unsettled by Greek), the visual interruptions worked by stage directions (both tabular registers and prose descriptions), and, above all, the printed marginalia, with their pointed clog of abbreviation and textual reference - the combined effect of all this is to produce a textual coruscation that disrupts the easy symmetries of verse array. ${ }^{30}$

This identification of the entry quarto as 'the first Jonsonian text to insist on the differences between the fugitive event and disseminable exfoliation' mark it as a crucial point in the development both of Jonson's sensibilities concerning authorship and text, and of his recognition of the potentialities of the printed book, particularly the printed drama. ${ }^{31}$ Loewenstein reads this as an important turning point for Jonson and perhaps for western literary culture more broadly, signaling a reorientation of the author's attitude to the phenomenology of the literary work. The text becomes transhistorical, anti-occasional, certainly antitheatrical. The text is what is authoritative.

Jonson's rhetorical choices thus contest the monarchic occasion's meaning and significance, but the material text participates in its own way. Reading the royal entry in print means reading Jonson's quarto as well as the other entry texts as not just their authors' intentions, but also as expressions of a print industry that was furiously commercializing and reacting to major changes in this period. Loewenstein's longstanding interest in Jonsonian authorship has led him more recently to the origins of intellectual property concepts. In key early chapters of The Author's Due, Loewenstein scrutinizes authorship and the state of the print industry in the 1590 s and early 1600s, finding a time when the growing commercialism of print unsettled the practices, traditional relationships, and even laws governing literary activity and print. Loewenstein unsurprisingly finds Jonson a key index of these changes, arguing that 'his writing and his behavior register crucial adjustments in the economic and cultural organization of intellectual property'. ${ }^{32}$ Jonson's at times obsessive attention to his works in print 'crowd[ed] the stationers' business', according to Loewenstein, but he was not alone in this at a time when the very success of print as a market was outstripping the industry's regulatory practices, heretofore always privileging its own, the stationers, over mere authors. ${ }^{33}$ 
Loewenstein observes 'the burgeoning culture of writing that print had fostered' and reviews both notorious and less well known cases in the history of print to convey a distinct climate of entrepreneurship, not only on the part of authors and emerging, copyright-challenging practices like authorial revision, adaptation, and textual augmentation, but also on the part of stationers themselves, as they came 'to recognize ... [that] their protections were imperfectly suited to [new authorial practices]'. ${ }^{34}$ And while Loewenstein's primary interest is to explicate 'the institutions that interpellate English authorship' and thus the contests that begin to tip agency towards the author, his meticulous survey vividly signals the contests and ambitions of and between stationers. ${ }^{35}$ We can therefore read Jonson's quarto so easy to construe only in terms of authorial ambition and desire for control — as a more complex sign of intellectual property. The quarto is perhaps just as much an expression of his publisher Edward Blount's ambition and competitive desire for control over the highly popular commodity of a recent royal entry in print.

Such an approach provocatively reframes known bibliographic details of Jonson's quarto as well as the other entry texts. The Stationers' Register shows that Blount, its publisher, entered Jonson's quarto on 19 March 1604, a mere four days after the royal entry occurred and about two weeks ahead of Dekker's (entered by Thomas Man the younger). Jonson's alacrity might suggest a rhetorical interest in gaining interpretive authority, but Blount's conveys a strongly commercial awareness of public interest in such a print edition, not to mention a competitive awareness of fellow stationers. Three of the four textual editions of this royal entry were rushed into print: Ralph Blore entered Dugdale's prose, eyewitness account into the Stationers' Register on 27 March 1604, just nine days after Jonson's entry, and Man registered Dekker's quarto on 2 April 1604. The Dekker quarto's print record moreover indicates a great desire for speed, according to Greg and Fredson Bowers, with up to five different compositors used to produce different sections of the text. The Stationers' Register offers an addendum to these hastily registered and produced versions, as well, that vividly suggests a contest of economics and intellectual property and even further reframes the significance of these printed pageant texts as expressions of stationers' control over material and commercial practices. On 14 May 1604, the Register lists this entry:

Edward Blount, Thomas Man, jun.: for the ending of the controversie between them about the booke of the pageante it is ordered that Edw Blount shall deliver all his remainder thereof (which he sayeth are 400) to Thomas Man. Receavinge of him viS [6 shillings] for every Ream thereof. Which it is ordered the said Thomas Man shall pay unto him. ${ }^{36}$ 
Blount explicitly is ordered to surrender all remaining copies of the Jonson quarto to Dekker's publisher, Thomas Man the younger. The exact nature of this conflict between Blount and Man is difficult to determine; no additional details have surfaced about it beyond this Stationers' Register entry. But Loewenstein's attention to the changing terms of intellectual property in the period's burgeoning marketplace of print suggests the clear economic stakes of ownership of these works. A lack of evidence that it was driven by a larger political concern such as royal licensure supports the claim that this dispute concerns economics and possible intellectual property violation. The politics at stake here involve the ways in which both the quartos and this Stationers Company entry effectively diminish the presence and significance of the king. What emerge instead are questions of economic authority and the powerful influence of the printers and publishers of the Stationers themselves. The dispute between Blount and Man the younger, and particularly the order for Blount's capitulation to Man, is reframed precisely as political and economic by a detail supplied in Herford and Simpson. They note that Thomas Man the elder (father of Man the younger) became master of the Stationers Company in 1604. ${ }^{37}$ Whether this fact played a role in the injunction, it reveals an additional non-artistic and non-authorial texture to the contests of the printed books of the 1604 entry.

\section{Dekker}

In contrast to Jonson's self-consciously exclusive text, Thomas Dekker's The Magnificent Entertainment presents and reperforms the entire royal entry. In an important sense, Dekker reverses Jonson's privileging of the readerly experience, reinforcing what was visually available as he describes either in summary or in detail all of the day's pageantry, including the contributions of the Dutch and Italian merchants, of Ben Jonson, and of Stephen Harrison. Dekker's comprehensive inclusions and his implied recreation of the event seem generous but also rebut Jonson in ways that signal Dekker was an equally self-conscious competitor for authority over the event, and, indeed, was an equally ambitious explorer concerning the rhetorical possibilities of print. Dekker creates a distinctly different text and reader's experience compared to Jonson's, but his text — indeed several texts - is just as innovative, and in these innovations even more challenging of authority over the event and of existing practices of pageantry in print and of the print industry.

Dekker's full title for his entry text immediately suggests its comprehensive intentions and the sense of capturing an occasion: 


\author{
The \\ Magnificent \\ Entertainment: \\ Given to King James, Queene Anne his wife, \\ and Henry Frederick the Prince, upon the day \\ of his Majesties Triumphant Passage (from \\ the Tower) through his Honourable Citie \\ (and Chamber) of London, being the \\ 15. of March. 1603 [1604]. \\ As well by the English as by the Strangers: With \\ the Speeches and Songes, delivered in Seve- \\ rall Pageants. \\ [epigraph from Martiall]. \\ Tho. Dekker. \\ Imprinted at London by T.C, for Tho.Man. \\ the yonger. $1604 .^{38}$
}

Compared with Jonson's title-page — which Adrian Weiss reminds us 'functioned as the modern dust jacket in advertising [a] book' ${ }^{39}$ — Dekker vividly features the event and, especially, magnificence. The entertainment itself was magnificent, but the prominence of the king and royal family in the title implies that this magnificence derives from the king himself and that Dekker merely recorded it all. Early in the text, he underlines this apparently modest and more populist role and pointedly skewers Jonson as a pompous rival:

To make a false flourish here with the borrowed weapons of all the old Maisters of the noble Science of Poesie, and to keepe a tyrannical coyle, in Anatomizing Genius, from head to foote, (only to shew how nimbly we can carve up the whole messe of the Poets) were to play the Executioner, and to lay our Cities household God on the rack, to make him confesse, how many pair of Latin sheets, we have shaken and cut into shreds to make him a garment ... The multitude is now to be our Audience. ${ }^{40}$

Dekker's readers, he suggests, will in an important sense be no different than the masses in the streets who witnessed the spectacle, and he employs the same terms for readers and reading as for observers and theatrics: 'The multitude is now to be our audience'. But much else in this text belies such a humble affect, including rhetorical details and choices and a distinctly entrepreneurial print and 
production record that, as with Jonson's, expands these quartos' contest beyond the artistic and rhetorical to the economic and material.

As noted above, at least five different compositors printed the first edition very quickly in April 1604, a production decision that the book's publisher, Thomas Man, would have made and paid for ostensibly in an effort towards the swifter appearance of Dekker's version while the entry and a printed record of it was in high demand, commercially. While Greg and Bowers ascribe this choice with certainty to a desire for speed, Adrian Weiss speculates at length about the relative significance of such 'shared printing' in the period, and specifically the act of 'simultaneous printing' of a book's range of signatures. ${ }^{41}$ Weiss does not find conclusive evidence of Dekker's quarto having been printed distinctly faster (we have no certain record of how soon books appeared for sale), but he notes that such a division of labour among four other printers in addition to main printer Thomas Creede, does 'imply circumstances which occasioned strategy' 42 The use of five printers - where the sharing of work between two printers was more common - underlines this sense of strategic printing and also suggests a climate of competition between not only poets but stationers, described above with Jonson and Blount. ${ }^{43}$ Weiss's and Peter Blayney's work on early modern printing paints a picture of 'intense fraternal competition' between stationers, especially over possession of what Thomas Nashe called a 'hot text'. ${ }^{44}$ Blayney explains that 'the owner [of a book, of 'coppy'] could seek the Stationers' Court's protection if any book - not necessarily a reprint or plagiarism of his book — threatened his ability to dispose of unsold copies of an existing edition', 45 and with this, Thomas Man's highly commercial concern over entry texts as goods becomes provocatively clear as a motivation for the dispute between publishers Blount and Man over the Jonson and Dekker quartos. 'The tangled web of relations between authors and publishers seems to underlie the settlement ordered by the [Stationers'] Court on 14 May 1604', Weiss argues, adding a claim that echoes Blayney and drives home the material stakes for Man and for publishers and printers in general: 'more than likely Man wished to eliminate Blount's book as competition' 46

Details of the quarto's attribution and of Stationers Company rules and protections of the time further underline Man's meticulous protection of Dekker's entry text as a valuable commodity. A Stationers' Register entry for 2 April 1604 lists The Magnificent Entertainment as entered by Thomas Man the younger and licensed by 'Pasfield'. This Pasfield is Zachariah Pasfield, and he was not a stationer but a Prebendary of St Paul's. Greg lists Pasfield as one among a group of non-stationers — almost all religious officials — allowed to license books for print. Discussing licensing, 'authority', and 'entrance' at length, Blayney describes 
license - an official sanction and increasingly interchangeable with 'authority' as a term in the period - as necessary for legal printing; 'entrance' in the Stationers' Register was not similarly required. That Man did officially enter Dekker's quarto indicates a desire for greater property protection, according to Blayney. He writes, 'Entry was an insurance policy: paid for, it provided the best possible protection' from the Stationers' Court. Entrance could signal concern about a popular book that could attract 'piracy' or 'anticipated problems of infringement'. ${ }^{47}$ Given the ensuing dispute, Thomas Man the younger was either amazingly prescient, or he was simply a savvy entrepreneur working with a hot text in the very hot 1604 marketplace of print.

Dekker's, or perhaps more rightly Man's, quarto also quickly reappeared as a newly titled second edition, The Whole Magnificent Entertainment, and detailed bibliographic study of changes and continuities between the two editions has suggested to Bowers that this second edition was planned all along and in a manner that would circumvent Stationers Company regulations 'limiting the number of impressions which could be taken from given typesetting. ${ }^{48}$ Evidence from The Arch's of Triumph indicates that Harrison was working from this second edition of Dekker's text, which means it was printed very soon after the first edition in April. This second edition was also published by Man and once again involved work by up to four other printers besides the main printer listed on the title-page. This listed printer is not Creede for this second edition, however, but Edward Allde, a change that may further signal Thomas Man's entrepreneurial savvy in shopping around for printing deals, a practice that Weiss describes as part of the increasingly competitive print climate. Bowers finds evidence of Dekker's hand in some corrections in the second edition (also noting errors puzzlingly not corrected), however, so Dekker's involvement in revising or augmenting his original edition seems clear, including his contribution in June 1604 of a prefatory ode to Harrison's Arch's of Triumph. Dekker and Man both demonstrate a savvy sense of the power of print and the commercial opportunities of this market.

This commercial sensibility is made even more vivid by the different treatment of several lengthy Latin speeches in the quarto's first edition and its second. The vast majority of spectators would not have understood these orations on the day; even for those who could understand Latin, their hearing of any speech was likely to have been incomplete due to noise and limited hearing range. Yet here in print the speeches are complete, and in the second edition they appear with the addition of English translations that make them fully available to all readers. In recent work on royal entries, Janette Dillon has noted the value, ideologically and politically, of the sheer incomprehensibility of royal pageantry for 
most spectators - these events' dense symbolism and use of learned languages like Latin were meant to overwhelm in combination with the visual splendour. In this light, the second edition's attention to translation and demystification seems populist in spirit, refusing exclusively elite ownership of the event. ${ }^{49}$ But on the heels of much other investigation, here, of not only the rhetorical but also the material, commercial story of Dekker's quartos, such translations in a swiftly offered second edition - indeed a 'new' edition that was largely printed from existing type of the first edition ${ }^{50}$ - suggest acute awareness of an economic as much as an interpretive opportunity.

To explicate the competitive nature of these quartos as material texts is not to omit attention to Dekker's rhetorical achievements and innovations. If the vivid single-mindedness of Jonson's quarto, both rhetorically and typographically, makes it somewhat easier to read and to assess according to terms of literary achievement that Jonson himself helped shape, Dekker's Entertainment text nonetheless is significant in terms of pageantry in print. Although critics have often underestimated Dekker, in the entry texts his exploitation of print's possibilities and authority is just as significant as Jonson's. The Magnificent Entertainment is most striking in terms of its hybridity, with a range of established and emerging print genres of the period used or gestured to over the course of the text's account, including the chronicle history, the manual or guide, and the 'Survey'. ${ }^{51}$ The effect is an inconsistency of tone and a lack of clear artistic unity; we should not, however, mistake these features for a lack of sophistication but rather see them as a desire to create an unprecedented type of record. The quarto opens with chronicle-like language describing the passing of Elizabeth I and the peaceful succession of James I: 'All mens eyes were presently turnd to the North, standing even stone-stil in their Circles, like the points of so many Geometricall needles ... to behold this forty-five yeares wonder now brought forth by Tyme'. ${ }^{52}$ The loftiness of tone and connection to a larger historical scope feel familiar, if not explicitly from Tudor chronicles like that of Holinshed, then from the late-Elizabethan chronicle adaptations made popular on stage and in print by Shakespeare and others.

Dekker's text also veers regularly away from the chronicle-esque. Perhaps appropriately for an authorized account of an important civic pageant but more incongruously alongside poetic cadences, The Magnificent Entertainment is at times a practical manual of the day's events and handbook of what it took to present them. Dekker describes a process of city officials being selected to commission and manage the pageant's development and presentation; he names the principal workmen as well as the numbers of 'Joyners', carpenters, turners, 
laborers, sawyers, 'plommers', 'smythes', and molders. ${ }^{53}$ These details read like an official civic contract, yet earlier in the text Dekker's description of the pageant's organization uses more poetic terms: 'a Select number both of Aldermen and Commoners (like so many Romane Aediles) were (Communi Consilio) chosen forth, to whose discretion ... [all] was ... committed'. ${ }^{4}$ Such aggrandizement sits oddly next to the pragmatic language of a guide or manual, a collision between an older but still significant pageant rhetoric and a newer informational style that was on the rise with the expanding market and readership of printed works in the period. ${ }^{55}$ Dekker splits the difference and uses both, a choice that is at times awkward but also attuned to the diversity of popular prose.

Dekker employs a much commented upon, physics defying style of description throughout his quarto: we scale with him the monumental arches that would only have been viewed from street level by spectators on the day, including the king, and he also frequently employs the second person voice in present tense: 'From whome, leade but your eye, in a straight line, to the other side ... and there [you will see]'.56 This style further evidences Dekker's exploitation of print culture in two distinct ways, drawing on still consolidating ideas of textual stability, superiority, and authority, and participating in an important new print genre in the period, the city view. The city view was a genre depicting urban place that grew out of the emergence of recognizably modern, accurate maps of countries, provinces, and full regions of the globe. ${ }^{57}$ In the words of Richard Helgerson, describing the implications of these cartographic advances in the period, 'for the first time [the English] took effective visual and conceptual possession of the physical kingdom in which they lived'. 58 Descriptions of place - chorographies - also began to appear in poetry and prose: William Camden's Brittannia (1586) and Michael Drayton's Poly-Olbion (1612) both belong to this new genre of place, as does Stow's Survey of London (1598), which importantly marked the direction of cartographic and chorographic energies toward cities, London most of all. New perspectival views of London proliferated from the 1570s into the seventeenth century, and many of these texts, whether in the visual format of a broadside or as inexpensive printed books, were available from the booksellers also proliferating over the same period in the city. ${ }^{59}$ Dekker's description of the royal entry regularly incorporates chorographic description, and his text offers a selective view of London alongside others increasingly available:

The streets are surveyed; heights, breadths, and distances taken, of ground (like so many fields for a battaile) are plotted foorth, upon which these Arches of Triumph must shew themselves in Glorie ... The streets seemed to be paved with men; stalls 
instead of rich wares were set out with children, open casements fild up with women. All glass windows taken down, but in their places, sparkled so many eyes, that had it not been the day, the light which reflected from them, was sufficient to have made one ... A goodly and civil order was observed, in Martialling all the Companies according to their degrees: The first beginning at the upper end of Saint Marks Lane, and the last reaching above the Conduit in Fleet Street. ${ }^{60}$

Dekker's ceremonial tone and the grandeur of a spectacular occasion are ever present in his quarto, but in passages such as these we also get material, logistical details as well as emphases on the experience of city dwellers in the streets that day. Lawrence Manley and Helgerson have argued that chorographies like Stow's Survey memorialize place in terms of local topography, history, and identity, not in terms of political/monarchic allegiance. ${ }^{61}$ And Dekker's descriptions of the city underneath the pageantry make Stow-like observations that emphasize the city's identity and existence independent of the king. This point becomes particularly clear near the end of the text, where Dekker makes a decorous flourish regarding the king's departure from the now bereft city that nonetheless suggests the city's autonomy and integrity:

And thus have wee (lowely and aloof) followed our Soveraigne through the seven Triumphall gates of this his Court Royall, which name, as London received at the rising of the Sunne; so now at his going from her ... She lost that honour: And being (like an Actor on a Stage) stript of her borrowed Majestie, she [resumes] her former shape and title of Citie. ${ }^{62}$

Here, though he mourns London's loss of its name and status as 'Court Royall', Dekker also signals that city and king are distinct and that the city without the king will nonetheless retain her shape, title, and identity of 'Citie'. The historical, physical fact of the city as well as the printed text itself imply sources of authority other than the king. His quarto's forays into genres gaining prominence with the rise of print culture in the period clarify Dekker's not at all naïve interest in the powers of print.

Such participation in new print genres conveys a self-conscious authorial sensibility that I argue we must compare with that of Jonson. And Dekker similarly uses the capacities of print to provide his readers with an experience of the pageantry even more exclusive than the king's. This print-based provision begins in his quarto's first pages when Dekker reorders the entry's events by beginning not with the first performed pageant of 15 March 1604 at the Londinium Arch 
but with a pageant Dekker had composed in 1603 as part of the first plans for the new king's London entry. As Dekker explains in the text, 'The Device following was ... made up, as the first service, to a more royall and serious ensuing Entertainment; And this ... should have been performed about the Barres beyond Bishops-gate.' ${ }^{63}$ The text then presents the speeches from this pageant, with Saints Andrew and George at its centre, before abruptly concluding that 'This should have been the first Offring of the Citties Love: But his Majestie not making his Entrance (according to expectation) It was ... but layd by. ${ }^{64}$ The effect of this pageant's inclusion as well as Dekker's explanation is ambiguous: while he seems at pains to point out the change in plans and the pageant's resulting exclusion, his clarification asserts the authority of his primary role in the entry's planning. The inclusion of the laid by pageant, moreover, powerfully reinstates it as the entry's first event in this print encounter.

As The Magnificent Entertainment progresses, Dekker's editorial intrusions and exhortations to his readers become more frequent and vivid, almost as if Dekker is gaining confidence in his and his book's ability to render this exceptional experience. He speaks metaphorically to the reader in the transition between the Italian and the Dutch merchants' pageants, for example, of 'Having hoysted up our Sailes, and taken leave of this Italian shore'. ${ }^{65} \mathrm{~A}$ few pages later he is giving instructions, asking for readers to 'Suffer your eyes to be wearied no longer with gazing up so high', and to 'leade but your eye, in a straight line, to the other side, (over the contrary Posterne) and there in a second upper Picture you may meete with two other Kings'. ${ }^{66}$ Soon after, Dekker's directions become plainly fantastic, as he explains to readers how they might 'with little labour, walke into the Mart' presented by the Dutch merchants high up on an upper level of their arch. Just a few lines later he appeals to his readers, 'Let us now clime up to the upper battlements; where, at the right hand Time stands: at the left (in a direct line) his daughter Truth'. ${ }^{67}$ Through all of this, Dekker's narration makes the reader a progressively more powerful figure, the sense of past event and present account increasingly blurred. Describing the stagings that accompanied the king's approach to the Garden of Plenty Arch (Hortus Euporiae), Dekker comments, 'But, least leaping too bluntly into the midst of our Garden at first, we deface the beautie of it, let us send you round about it, and survey the Walles, Allies, and quarters of it as they lye in order. ${ }^{68}$ Over and over again — despite the quarto's ostensible focus on the king and on the day's events as spectacular celebrations of the king and his family - the descriptions, the editorial comments and directions, and the details made available through the printed text construct the reader 
as an all important agent in the experience while also underlining Dekker's artistry and role as knowledgeable leader.

And then there is the closing note, 'To the Reader', that appears in the first edition but curiously not in the second. He writes, 'Reader, you must understand, that a regard, being had that his Majesty should not be wearied with teadious speeches: A great part of those which are in this Booke set downe, were left unspoken: So that thou doest here receive them as they should have bene delivered, not as they were'. ${ }^{69}$ Here, along with deferential concern for the king, there are notable assertions of Dekker's and of print's authority. Dekker becomes not just a recorder but a bold truth teller when he admits that much of his quarto's content was not performed on the day. With this statement, he shares a fact but also neatly performs a self-authorizing role as supplier of what was unavailable. ${ }^{70}$ With the final sentence in this note, Dekker more overtly claims control, clearly asserting the greater authority of his printed text over the event in a manner observed by Peters, as described above, and often associated with Jonson but not with Dekker. I would argue, however, echoing Wall, that the authority claimed here does not derive simply from the printed text's safety from the mutilations of performance but from the way that Dekker underscores his powers as an author, calling attention to his role in 'governing the flow of the text'. These are Wall's words in reference to Mulcaster and his printed book of Elizabeth I's entry. Wall's analysis of the precise relationship between performance and printed text provocatively reframes Dekker's Entertainment and the workings of its authority as she brings in the Derridean idea of the supplement to consider Mulcaster and his role in this 1558 entry text:

When Mulcaster calls attention to his role in governing the flow of the text's interpretation, he appropriates the pageant's power for his own ends. His printed account supplements, in the double sense that Derrida teases out of the term when discussing the function of the sign itself, the social force of spectacle. Because the supplement adds to something that is ostensibly already complete and whole, it is an unnecessary and troubling addition; but because it also completes that entity, it calls attention to the inherent lack that makes the addition necessary. ${ }^{71}$

Some of the dynamics Wall here theorizes with Mulcaster's text surely were altered somewhat by 1604 , with the much increased commerce between the theatrical scene and printed page. But this change would only have intensified the sensibility Wall identifies as early as Mulcaster's book — that publication was necessary for official events to be 'complete'. More and more, and vividly in Dekker's 
quarto, 'the text did not have to rely on the drama of the spectacle; it could produce that moment of display on its own authority'. ${ }^{72}$ Dekker's Magnificent Entertainment was a printed edition and addition to the events of 15 March 1604, both subtly and overtly pointing to the actual pageant's inadequacies and to its several quartos' control and completeness.

\section{Harrison and Dugdale}

Jonson's and Dekker's texts have received the most critical attention over time, but they represent only two of the four initial print versions of James's royal entry; exploring the royal entry as most importantly a print event means extending attention beyond Jonson and Dekker to Stephen Harrison's elaborate folio featuring engravings of the pageant arches, and to Dugdale's eyewitness account. Both texts also belong to a project of reevaluating civic pageantry in print, considering both its untidy urban context and complex marketplace. Bringing in Harrison's and Dugdale's texts emboldens a revised understanding of an event far from uniform in its signification that, particularly in print, becomes a series of self-conscious authorial and commercial contests.

Harrison's The Arch's of Triumph suggests a talented craftsman with genuine architectural training who was also an adroit participant in the competition for artistic control over the entry and commercial control of the market for it in print; The Arch's of Triumph is a highly competitive text on both levels. Harrison presents it self-consciously as a valuable commodity. With its folio format and the fine engravings it features of all seven triumphal arches, this book offers an unprecedented visual record of civic pageantry in the period that Martin Butler has described as 'the single most important illustrated English festival book from the period'. ${ }^{73}$ And Harrison is not shy in calling attention to his book's unique significance. In the dedication to the lord mayor that follows the titlepage, Harrison stresses not his artistry in building the arches but the artistry of his book that will now resurrect the king's entertainment 'and shall endure forever. For albeit those Monuments of your Loves were erected up to the Cloudes, and were built never so strongly, yet now their lastingness should live but in the tongues and memories of men: But that the hand of Arte gives them here a second and more perfect being. ${ }^{74}$ Here, Harrison admits the fundamentally ephemeral nature of pageantry, including the spectacular arches that were his contribution, only to reclaim his agency as the one responsible - with the help of engraver William Kip — for 'the hand of Arte giv[ing]' permanence. In this assertion of such permanence of art we might see a faint retort to Ben Jonson, whose own text enacts the poet's belief in the superiority and permanence of words over the visual. 
Harrison's rhetoric suggests keen awareness of his text as competing with this rival idea of artistic value and permanence, and striving for commercial success based on such value and permanence. Such artistic and commercial competition is also detectable in Harrison's disingenuous apology for the delay in the book's appearance: 'yet in regard that this present Age can lay before you no President [sic] that ever any in this land performed the like, I presume these my endeavors shall receive the more worthie liking of you' ${ }^{75}$ Couched in a ceremonious dedication, these pronouncements of Harrison's advertise its singularity as an edition of the recent pageantry and as a desirable product.

And it was quite a product, as implications of its format and production make clear. Before turning to further discussion of content within The Arch's of Triumph, some of the book's material story vividly augments the picture of Harrison's text as a competitor. The text's production as a folio edition, not a quarto like the others, enhances its status as an expensive and special object. Simply based on paper costs, and factoring in the standard print run of 800 copies, ${ }^{76}$ a folio size edition would have been considerably more costly to print, and thus to sell, than a more compact quarto; as Adrian Weiss describes, 'the choice of edition size and format directly influenced the cost of the paper. ${ }^{77}$ So this was a spectacular 'largeformat pageant volume', in the words of Loewenstein, ${ }^{78}$ that perhaps can be more easily aligned with earlier, chiefly ceremonious pageant editions like Mulcaster's in 1559. But Loewenstein and others have sought to place Harrison distinctly in the midst of the changing and entrepreneurial print marketplace with his edition, not above or adjacent to it. Bergeron's reverent description of Harrison as 'theorist, practitioner, historian, publisher, and cultural participant ${ }^{79}$ also implies a canny side to him, and both Bergeron and Loewenstein relate publication and sales details that further underline an entrepreneurial intent. While the book was printed by John Windet, printer to the City of London, Harrison served as both publisher and bookseller for his entry text. Bergeron tells us, 'As publisher, Harrison served in a sense as 'architect' for the book. He arranged for odes to be written by Dekker and John Webster for inclusion ... He engaged William Kip to make the engravings. The book itself manifests a self-consciousness about the product as book'. ${ }^{80}$

Loewenstein reads these details more materially and as even more indicative of Harrison playing a role in a competitive, commercial market. He discusses Harrison's selling of Windet's printed stock — 'to be sold at the Authors house in Lime-street, at the signe of the Snayle' 11 — as a notable example among many in this period of authors increasingly 'crowding the stationers' business. ${ }^{82}$ Bookselling was a distinct component of stationers' business, and while it was not 
unusual for a printer to also sell printed stock, bookselling — like publishing and printing - was a zealously guarded company right. Loewenstein ultimately sees Harrison's unusual appropriation of the role of bookseller for his text as not particularly egregious given that stationers often paid authors in kind for their manuscripts, but the arrangement in fact is unusual, since it was more common for only a small number of 'presentation copies' to be given an author, whether for keeping or for further sales. As Loewenstein describes, after 'the City of London paid the printing costs for this lavish illustrated volume ... Harrison simply extend[ed] the practice [of obtaining presentation copies as payment], securing his reward by selling not just a few but all of his books'. ${ }^{83}$ A lucrative arrangement for Harrison, most likely, it also registers, via Loewenstein in particular, as a distinct node of a larger climate of changing authorial control and heightened awareness of the commercial value of printed books.

Within The Arch's of Triumph, such self-consciousness as a book and as a product continues. The volume borrows from and makes references to Dekker's Magnificent Entertainment text, signaling an artistic collaboration but also an attunement to the significance and success of another book on the market, and Harrison foregrounds his own text's book-ness in several ways. A varied selection of narrative and descriptive text (including summary description of each arch, architecturally and symbolically; some summary and some reproduced scripts of speeches given; and a little dramatic dialogue) accompany Harrison's presentation of the images of the different arches. But as Harrison makes clear in his closing note to readers, he is not attempting to provide a full text of the 15 March pageantry; one can go to Dekker for that, he seems to imply. Instead he picks and chooses, crucially repackaging conventional descriptions of the pageantry and elements of its scripts with engravings he commissioned, with material details of the arches' construction, and with a few eyewitness-like observations, all to create a book about The Arch's of Triumph, not about the royal entry.

A range of paratextual apparatus even more vividly indicative of self-consciousness about the printed book as a book accompanies this exploitation of its literally composite nature. Harrison's inclusion of a 'Lectori Candido', a letter to the reader, makes explicit the book's (and author's) interest in readers and includes heretofore undescribed details of the entry and its pageantry that imply an exclusivity that is distinctly readerly: such an exclusive experience of the pageant is only available in book form, and in this book. Harrison writes, 'Nor shall it be amisse to give thee intelligence of some matters (by way of notes) which were not fully observed, nor freely inough set downe in the Printed Booke of these Triumphes: amongst which these that follow are chiefest'. ${ }^{84}$ Some of the privy details shared 
include the specific times that the king began and concluded the entry progress; the precise first sight encountered by the king (not the first arch, we learn); and the lengthy extent over the progress route of the liveries of the many city companies. We see similar letters to the reader in numerous printed works of the period, of course, and indeed we find apparatus specifically directed to readers in both Jonson's and Dekker's quartos of the entry. But this similarity is part of the point. Harrison's Arch's of Triumph participates, indeed competes, as avidly as Dekker's and Jonson's editions, in the burgeoning marketplace of print of the period. With all three texts in view, not only is this awareness of the market more evident, but so is their competition with each other and with - despite rhetorical flourishes to the contrary - the royal context of the occasion, as each book asserts its powerful supplemental status and work. The Arch's of Triumph reveals a vivid intertextuality with Dekker and with Jonson that ultimately is more prominent and powerful than the king in any of the three works.

Alongside them, Dugdale's The Time Triumphant is a more minor work, but it holds significance as an eyewitness account and as yet another printed book of the royal entry. David Bergeron, who deserves credit for his longstanding calls for critical attention to civic and royal pageantry, argues strenuously for inclusion of Dugdale's text in any treatment of the royal entry: 'we must add him to the list of essential texts ... for a study of the pageant. ${ }^{85}$ I heartily agree, and Dugdale's text notably is included as one of the entry texts in Butler's 2014 textual essay on 'The King's Entertainment' in the Cambridge Jonson. ${ }^{86}$ But Bergeron's emphasis is on the value of Dugdale's text to get the fullest picture of the royal entry, to enable a kind of more perfect transparency to the event. I suggest that its greatest significance lies in the way it augments a reading of the entry as a set of print contests, placing the other texts and their contests into further relief. ${ }^{87}$ Dugdale's text was entered into the Stationer's Register on 27 March 1604, thus right between the entry dates of Jonson's (19 March) and Dekker's (2 April) texts. Ralph Blore entered and printed it, but his name does not appear in Greg's list of licensers, publishers, printers, and booksellers producing drama in print between 1516 and 1616, as do those involved with Jonson's, Dekker's, and even Harrison's texts. This use of a printer unconnected to the industry of printing drama in one sense is unremarkable since Dugdale's text is a descriptive account, not a dramatic work. But Blore's (or Blower's) involvement lends a sense of competition beyond just the entrance timing, as he was a printer apparently well known, even notorious, for low quality and thus, presumably, for speed. Peter Blayney suggests as much in his account of the process of bringing a manuscript through the process of production: his imaginary stationer seeking economy will 'rule out ... printers 
with fairly high standards of craftsmanship' and will therefore seek lower priced printers, but hopefully 'without necessarily going to the ... extreme [of] Ralph Blower (1595-1619)'.88

This implication of a speedily produced but markedly low quality text contrasts with the other three entry texts and perhaps signals quite different anticipated buyers and readers; is it truly accurate to read these books as competitive? My answer remains yes, despite some readership differences likely compelled by cost as well as quality, as Dugdale's text along with Blore's entrance and swift, cheap creation clearly suggest an impulse to cash in on a popular event and on the commodity of a cheap print version amid other versions in process. Such a spirit of economic intervention can also be found, I would argue, in the black letter font of Dugdale's text, a choice most likely made by Blore himself as printer, not Dugdale. Weiss offers extensive discussion of the significance of black letter typeface in the period, his comments pointing suggestively to Blore's black letter as a choice that marked The Time Triumphant as a particular kind of commodity for popular consumption. Weiss disavows Keith Thomas's prominent notion 'that black letter was the ... commoner's typeface, ${ }^{89}$ offering examples of children's $\mathrm{ABC}$ and catechism texts in the period that incorporated roman and italic typefaces along with black letter, and pointing to Holinshed's Chronicles and Spenser's Shepheardes Calendar as prominent, elite works printed in black letter, examples that would seem to refute the idea of black letter as the domain of non-elite texts. Yet he also acknowledges that black letter clearly was 'a signifier' and 'created an ambiance ... a sense of 'ancient authority'. ${ }^{90}$ Black letter was a distinct choice as a typeface by 1604 , and perhaps a way to evoke not only archaism but also a sense of history, perhaps of historical authenticity. Of course, if Blore was as shoddy a printer as Blayney notes, black letter might simply have been what he had easily to hand for the Dugdale manuscript, but the distinctly signifying rhetoric of black letter, as explored by Weiss, additionally marks Dugdale's entry text and implies a self-conscious intervention in any existing print discourses of the entry.

The Time Triumphant and its descriptions of a spectator's experience amplify how much Harrison's, Dekker's, and Jonson's texts are not simply records but distinct creations utilizing a rhetorical range that included, as we have seen, that of the printed book itself. One striking discrepancy between Dugdale's account and these others offers an idea of the textures brought out by the former. In his account of the entry, Dugdale describes an interlude involving Sts George and Andrew occurring very early in the proceedings, at the early point of Jonson's Londinium Arch pageant. ${ }^{11}$ This description is provocative, for none of the other three works indicate this additional performance before, during, or after the 
Londinium pageant: Dekker, as we have seen, prominently includes a planned action involving these two patron saints in his text but laments that it was, in the event, 'laid by'. Dugdale's account thus raises questions about both Dekker's and Jonson's textual presentations. If Dugdale is accurate, then Dekker's quarto even more cleverly asserts Dekker's control over the pageant by, instead of including his St George and St Andrew pageant alongside the Londinium arch where perhaps it was in the end included, opening his text with it, materially enacting his authorial preeminence over the day. Even his regretful or apologetic editorial comment that his pageant was laid by (now less certain because of Dugdale) appears as yet another way to assert his prior authority concerning the pageantry, all the way back to its earliest planning in 1603. And as for Jonson, if Dugdale is accurate, then Jonson's presentation of his Part as an artistically coherent whole with no other added components is even more a competitive and exclusionary expression. Jonson's manipulations of the overall event to serve as a vehicle for his art already are fairly clear, but imagining Dekker's interlude as an actually staged addition, preamble, or postscript to Jonson's own opening creation makes his textual choices that much more urgent and reordering.

Dugdale's text does some reordering of its own, as well. Most notable is the presence in The Time Triumphant of two speeches and accounts of them as part of the pageant day's events that appear in none of the other three entry texts. Bergeron describes the two speeches' presentation in Dugdale's text and characterizes them as 'significant verbal addition[s] to the pageant', even while noting that these reported episodes occur 'only in Dugdale's report' and while raising questions about how Dugdale could know and present them as he does, verbatim. ${ }^{92}$ Of the second newly included speech, made apparently by an apprentice from the top of the great conduit in Cheapside, Dugdale admits that, 'whether he spake this or no, I heard him not, but ye manner of his speech was this, coming to me at the 3. or second hand'. ${ }^{3}$ Bergeron is willing to accept Dugdale's report, for 'given his reportorial skills, one accepts the probable reliability of these events and speeches', ${ }^{94}$ but the relative legitimacy of the speeches to me matters much less than other levels of their significance, specifically the ways they render the text as in competition with other versions, including competition for sales. Dugdale's inclusion of a speech not prepared by a professional dramatist, the humble and sentimental speech of an 'old man', implicitly wrests a level of interpretive control of the event from dramatist, dramatist's text, king, or city; the speech's existence contests the accuracy of the other printed accounts and the speech's content challenges the playwrights' carefully worked out allegorical meanings of the event itself, as the old man describes the four previous monarchs he has beheld and 
offers the simple wish that 'thy change [ie death, change of king], to us that be alive, / Never be knowne, a fifth extreame to bring. ${ }^{95}$ Dugdale describes in his account that the old man's speech was 'overshadowd' by the noise of the multitude, but notes, 'I have publicly imprinted it that all his fellow Subiectes may see' it, ${ }^{96}$ an inclusion that reflects Dugdale's intention to provide an eyewitness account but also suggests the use of both speeches as a kind of news that distinguishes his entry text from all the others and, in this way, makes it a desirable commodity.

The most striking aspect of Dugdale's text is its exposure of the array of pressures and anxieties that accompanied the royal entry. In writing and publishing his account, Dugdale appears to have been invested in recording the event as seamlessly decorous and fully comprehendible. But the effect he creates is quite the opposite: his hyperbolic language, combined with an admission that the plague delayed the king's entry as well as a description of the king's nervous retreat into the Exchange, serve mainly to signal the king's and others' anxieties surrounding this long delayed formal ceremony and this new, foreign king. Here, Dugdale acts as a peremptory apologist for the king's awkward response to the London crowds, with Dugdale's efforts to rationalize the king's behavior as appropriate and even loving mainly exposing tensions:

And countrymen let me tell you this, if you h[eard] what I h[eard] concerning that you would stake your feet to the Earth ... ere you would runne so regardless up and downe ... you may note by the order of his coming [his love] [would] you then be publique and proclaime ... but your open ignorance ... you will say perchance it is your love [but] will you in love prease your Sovereign thereby to offend him, your Sovereign per[chance] [may] mistake your love, and punish it as an offence. But the narrow way, and the preasing multitude, so overshadowed [the speaker], and the noyse of the showe ... so that the King past by, yet noting [this speaker's] zeale I have publiquely imprinted it, that all his fellow subjects may see this old man's forwardness. ${ }^{97}$

These passages reveal Dugdale's account to be both factual and fictional, as he awkwardly presents actual events but also works to shape them and explain them. What gets revealed is less glory and more the fissures in the day's idealistic goals. And these effects in Dugdale's book work, again, to more sharply distinguish Jonson's, Dekker's, and Harrison's texts as the carefully wrought, authorial creations they are. If Dugdale's presentation is less than adroit, the very fissures he exposes heighten the other texts' artistry through their omission of these same breaches. 


\section{The Aftermath of Early Modern Print}

The Time Triumphant is an essential component of the print story of the royal entry because of the way that it reframes the other three texts, not only rhetorically but also as commercial products, and because of the ways it reprises questions about the material processes and uses of print. This printed account is also essential to this story because of the disorderliness it communicates and enacts alongside the comparably neater artistry of the other works. At the end of his account Dugdale includes a comment on the day's events that again suggests anxieties about the chaotic nature of the day:

The multitude of people at this present were innumerable: but to conclude God be thanked, for it, was such the great care of the worshipfull Citizens of London, \& all things so providently foreseen, by them, that little or no hurt or danger ensued to any: which was greatly feared of many, to have happened: by reason of the great multitudes that were in the Citie, being come both farre $\&$ neere thither. ${ }^{98}$

Despite its purpose and ideal as a decorous and deftly controlled event, this was far from possible amid the noise, press, and sheer numbers of people in the narrow streets of the city. A lot, apparently, could go wrong. And according to Dugdale some things did not go as planned, but in the end no one was killed. This comment establishes a very different set of stakes from the decorum Dugdale works to foreground elsewhere in his text, not to mention a very different set of stakes from the interpretive minutiae of, for example, Jonson's quarto.

My point is not that one set matters more than the other but that both sets and both texts, indeed all four texts, as well as second editions and reissues, matter to a more capacious, more materially grounded, and less orderly picture of early modern theatrics and culture. ${ }^{99}$ In this sense my conclusion aims not to be conclusive but instead to assert the indeterminacy of the intensely symbolic and ostensibly univocal entry introduced when we read printed texts. When Dillon describes the royal entry as, 'a delicate negotiation between the relative claims to possession and authority of sovereign and city', ${ }^{100}$ she captures important contentious qualities of the event, but the print story, as we have seen, reveals additional layers of possession, authority, and negotiation that existed and that could play out in material form long after the day of pageantry concluded. These four entry texts complicate and demand further rereading of many things in the period: of the entry itself and its civic/court negotiations; of civic and royal pageants, their public spectacles and their material afterlives; of the Stationers Company records and changing 
practices and protections alongside growing authorial control; of print culture in the period, broadly, and of the work of drama and theatrical events in print; and of Jonson, Dekker, and Harrison as artists and as entrepreneurs. In this context, pageantry such as the royal entry becomes, just as much as more popular dramatic forms and spaces, a site of potent and pervasive contests.

Perhaps the most striking contest that surfaces through attention to the 1604 entry as print concerns the king and his apparent centrality to this pageant's occasion, design, and meaning. As we have seen, these four printed versions render the entry as more than anything a textual stage not for the king but for vying interpretations and economic ventures. I do not suggest that the entry spectacle and the king's perceived magnificence were at all challenged on the day, or even that our authors' intentions were to challenge or undermine the king and his authority. But in print the 1604 entry is not a straight recreation of either spectacle or royal politics; instead, it is a new creation that implicitly and explicitly contests authority and preeminence other than its own, while it also exists as four individual creations that vie with each other and with a consuming, reading populace. Such an assessment of the pageantry and print culture of this moment both extends and modifies Wall's conclusions concerning print and monarchic authority. Wall writes that 'writing and publishing add a variable that complicates ... a reading of pageantry's politics' (114), and that 'monarchic authority becomes contingent on publication' (126). ${ }^{101}$ The dialectic exposed here is part of Wall's point, as she works through Mulcaster's 1559 edition of Elizabeth's entry and explores the tensions inherent in a growing monarchic reliance on print even as recognition of print's own authority and interpretive capacity is emerging. By the accession of James, more than forty years later and with a robust writing, printing, and reading culture occupying the same city space as a royal entry pageant, the same dialectic is greatly intensified. Or perhaps it is more accurate to say that it is emptied out, as the writing and publishing of the 1604 entry become in many ways more concerned with the politics and economics of authorship and print than the politics of pageantry. That is, according to Mulcaster in his 1559 text, 'Wordes do flye, but writing dothe remain'. 102

\section{Notes}

1 Gary Taylor and John Lavagnino (eds), Thomas Middleton: The Collected Works (Oxford, 2007), https://doi.org/10.1093/actrade/9780198185703.book.1. David Bergeron's career spanning interest in civic pageantry has played an important role 
in critical attention, but notable recent publications include Practicing Renaissance Scholarship: Plays and Pageants, Patrons and Politics (Pittsburgh, 2000), and a revised 2nd edition of English Civic Pageantry (Tempe, 2003). See also Tracey Hill, Pageantry and Power: A Cultural History of the Early Modern Lord Mayor's Show, 1585-1639 (Manchester, 2010).

2 Richard Dutton, Jacobean Civic Pageants (Edinburgh, 1996), 7; quoted in Hill, Pageantry and Power, 4.

3 Hill, Pageantry and Power, 14, 88.

4 Thomas Middleton: The Collected Works, 224.

5 Ben Jonson, 'The King's Entertainment', David Bevington, Martin Butler, and Ian Donaldson (eds), The Cambridge Edition of the Works of Ben Jonson (Cambridge, 2012), 2.420-450, http://dx.doi.org/10.3366/bjj.2013.0086; see also 'Part of the King's Entertainment in Passing to his Coronation', Herford and Simpson (eds), The Complete Works of Ben Jonson, (Oxford, 1925-52), 7.83-109; Thomas Dekker, 'The Magnificent Entertainment Given to King James', Fredson Bowers (ed.), The Dramatic Works of Thomas Dekker (Cambridge, 1955-61), 2.253-303; Stephen Harrison, The Arch's of Triumph (London, 1604; sTC 1025:16); Gilbert Dugdale, The Time Triumphant (London, 1604; sTC 955:17).

6 Bergeron in particular often seems concerned to arrive at this sense of completeness and accuracy — see Bergeron, Practicing Renaissance Scholarship. For recent studies that situate Jonson and Dekker's civic compositions as central to their larger oeuvres and read the entry as both text and performance, see D.J. Hopkins, City/ Stage/Globe: Performance and Space in Shakespeare's London (New York, 2008), esp. 103-46, https://doi.org/10.4324/9780203933701 and James Mardock, Our Scene is London: Ben Jonson's City and the Space of the Author (New York, 2008), https://doi. org/10.4324/9780203928516. For more traditional studies, see Jonathan Goldberg, James I and the Politics of Literature: Jonson, Shakespeare, Donne, and the Contemporaries (Palo Alto, 1989), http://dx.doi.org/10.2307/2905423; Graham Parry, The Golden Age Restor'd: The Culture of the Stuart Court, 1603-1642 (New York, 1981); and Gail Kern Paster, 'The Idea of London in Masque and Pageant', David M. Bergeron (ed.), Pageantry in the Shakespearean Theater (Athens GA, 1985), 48-64.

7 Graham Parry quoted in Bergeron, Practicing Renaissance Scholarship,189.

8 Thomas Middleton: The Complete Works (Oxford, 2007), 219.

9 Ibid.

10 Also notably included in this collated edition in the Middleton and further collapsing of a more complex print history is a title-page image from Harrison's The Arch's of Triumph but not from the 1604 edition described. This image in fact derives from the 1613 reprint of this folio volume - evident from the bookseller information 
included at the bottom of this title-page: sold by John Sudbury and George Humble. The 1604 original edition was sold out of Harrison's own house.

11 See also Bevington, Butler, and Donaldson, The Cambridge Edition of the Works of Ben Jonson (Cambridge, 2012) for the most up to date, scholarly edition of Jonson's text, 'The King's Entertainment'.

12 Thomas Middleton: The Complete Works, 219

13 Hill, Pageantry and Power, 13, 1.

14 See W.W. Greg, A Bibliography of the English Printed Drama to the Restoration (London, 1939) and A.W. Pollard, 'The Regulation of the Book Trade in the Sixteenth Century', The Library 7 (1916). Marta Straznicky, 'Introduction', Marta Straznicky (ed.), The Book of the Play: Playwrights, Stationers, and Readers in Early Modern England, (Amherst, 2006) lays out the implications both historical and critical for attending to the books of early modern plays with the dominance of the New Historicism in recent decades. As well, growing emphasis within literary studies on production instead of reception forms a clearer picture of a print marketplace; see Joseph Loewenstein, 'Printing and "The Multitudinous Presse": The Contentious Texts of Jonson's Masques', Jennifer Brady and W.H. Herendeen (eds), Ben Jonson's 1616 Folio (Newark, DE, 1991), 168-91 and Stephen Orgel, 'Marginal Jonson', David Bevington and Peter Holbrook (eds), The Politics of the Stuart Court Masque (Cambridge, 1984), 144-75. For historical studies of early modern print and the public sphere, see Alexandra Halazs, The Marketplace of Print: Pamphlets and the Public Sphere in Early Modern England (Cambridge, 1997), https://doi.org/10.1017/ CBO9780511581892; Julie Stone Peters, Theatre of the Book, 1480-1880: Print, Text, and Performance in Europe (Oxford, 2000), https://doi.org/10.1093/acpro f:oso/9780199262168.001.0001; and David Zaret, Origins of Democratic Culture: Printing, Petitions, and the Public Sphere in Early-Modern England (Princeton, 2000).

15 Lauren Shohet, 'The Masque in/as Book', Marta Straznicky (ed.), The Book of the Play, 143-68; Wendy Wall, The Imprint of Gender: Authorship and Publication in the English Renaissance (Ithaca NY, 1993).

16 Shohet, 'The Masque in/as Book', 145

17 Wall, The Imprint of Gender, 4.

18 Ibid, 114.

19 Joseph Loewenstein, The Author's Due: Printing and the Prehistory of Copyright (Chicago, 2002), 22-3, https://doi.org/10.7208/chicago/9780226490410.001.0001.

20 Ibid, 94.

21 Bergeron, Practicing Renaissance Scholarship, 170, 172.

22 For an excellent map of the route, see Lawrence Manley, Literature and Culture in Early Modern London (Cambridge, 1995), 226-7. See also Bergeron, English Civic 
Pageantry, 71-88 and Janette Dillon, The Language of Space in Court Performance, 1400-1625 (Cambridge, 2010), 18-48.

23 The 'War of the Theatres' rivalry between Jonson and Marston and Dekker is well known and exemplified in Jonson's 1601 comedy Poetaster. Paula Johnson, investigating the rhetorical and tonal differences between Dekker's and Jonson's 1604 entry pageantry, notes a 'Dekker-Jonson opposition'. See Paula Johnson, 'Jacobean Ephemera and the Immortal Word', Renaissance Drama 8 (1977), 156, https://doi. org/10.1086/rd.8.41917139.

24 In Herford and Simpson's edition Ben Jonson, a reproduction of 1604 quarto titlepage follows text page 7.79 .

25 Peters, Theatre of the Book, 129.

26 Mardock, Our Scene is London, 30.

27 Cambridge Edition of the Works of Ben Jonson, 2.439.

28 Ben Jonson, 7.209, my emphasis.

29 Loewenstein, 'Printing and "The Multitudinous Presse", 180.

30 Ibid, 180.

31 Ibid, 181-2. Loewenstein's particular interests in Jonson and authorship and in the rise of print has led to two recent monographs, each of which takes up this compound subject. The Author's Due broadens to a history of copyright and of intellectual property. See also Ben Jonson and Possessive Authorship (Cambridge, 2002), https://doi.org/10.1017/S0040557403400148.

32 Lowenstein, The Author's Due, 94.

33 Ibid, 95.

34 Ibid, 106.

35 Ibid, 23.

36 This note from the Stationers' Register has become well known and is quoted widely. Here quoted from Martin Butler, 'The King's Entertainment, A Panegyre, and The Entertainment at Althorp: Textual Essay', The Cambridge Edition of the Works of Ben Jonson, Online Edition (2014), http://universitypublishingonline.org/cambridge/ benjonson/k/essays/kings_entertainment_textual_essay/1, 1.

37 Ben Jonson, 7.78-9.

38 The Dramatic Works of Thomas Dekker, 2.229.

39 Adrian Weiss, 'Casting Compositors, Foul Cases, and Skeletons: Printing in Middleton's Age', Gary Taylor, John Lavagnino, and Trish Henley (eds), Thomas Middleton and Early Modern Textual Culture: A Companion to the Complete Works (Oxford, 2014), 224, https://doi.org/10.1093/actrade/9780198185703.book.1.

40 The Dramatic Works of Thomas Dekker, 2.254-5.

41 Weiss, 'Casting Compositors', 222, 223. 
42 Ibid, 223.

43 Peter Blayney provides an interesting additional note with this printing question that seems to underline matters of strategy and of self-consciousness about editions. In somewhat whimsical fashion, he describes printer Humphrey Lownes, one of the multiple printers of both of Dekker's 1604 editions, as well known for being careful and producing high quality work. See Peter Blayney, 'The Publication of Playbooks', John Cox and David Scott Kastan (eds), A New History of Early English Drama (New York, 1997), 405.

44 Weiss, 'Casting Compositors', 197.

45 Blayney, 'The Publication of Playbooks', 399.

46 Weiss, 'Casting Compositors', 198-9. Martin Butler also treats this dispute between Man and Blount, as noted in the Stationers' Register. Butler reads the implications differently, seeing Man as having capitulated to Blount. But even if the damages are reversed, either reading points indelibly to the 'hotness' of the market for these entry texts in the spring of 1604. See Butler, 'The King's Entertainment', 2-3.

47 Blayney, 'The Publication of Playbooks', 404.

48 The Dramatic Works of Thomas Dekker, 2.234.

49 Dillon, Language of Space, 21-2, 30.

50 See Greg, Bibliography, 1.321-2.

51 See Karen Newman, Cultural Capitals: Early Modern London and Paris (Princeton, 2007) on the emergence of topographical awareness in early modern cities. For important work on maps, map technology, and the cultural and political implications of cartographic awareness, upon which Newman builds, see Tom Conley, The SelfMade Map: Cartographic Writing in Early Modern France (Minneapolis, 1996); Richard Helgerson, Forms of Nationhood: The Elizabethan Writing of England (Chicago, 1992); and Rhonda Lemke Sanford, Map and Memory in Early Modern England: A Sense of Place (New York, 2002). Critical interest is expanding concerning Dekker as just such an experimental producer and adapter of emerging print genres. See Anne Bayman, Thomas Dekker and the Culture of Pamphleteering in Early Modern London (Hampshire, 2014), https://doi.org/10.4324/9781315551067.

52 The Dramatic Works of Thomas Dekker, 2.253.

53 Ibid, 2.303.

54 Ibid, 2.257.

55 Critical interest in and scholarship concerning the material dimensions of the literary and of literacy in the period steadily has grown in recent decades, as noted above with attention to plays as books. For a valuable digest of much earlier work on print and manuscript culture, literacy, and reading, see Heidi Brayman Hackel, Reading 
Material in Early Modern England (Cambridge, 2005) as well as Zaret, Origins of Democratic Culture, 136, 145-9, 150-9.

56 The Dramatic Works of Thomas Dekker, 2.269.

57 See Sanford, Map and Memory, 3-4 and 13-16.

58 Helgerson, Forms of Nationhood, 107.

59 On the proliferation of cheap printed books and of booksellers in the period, see Zaret, Origins of Democratic Culture, 147-59. See also David J. Baker, On Demand: Writing for the Market in Early Modern England (Stanford, 2010), 7, https://doi. org/10.11126/stanford/9780804738569.001.0001.

60 The Dramatic Works of Thomas Dekker, 2.258, 258-9. 267.

61 Lawrence Manley, 'From Matron to Monster: Tudor-Stuart London and the Language of Urban Description', Heather Dubrow and Richard Strier (eds), The Historical Renaissance: New Essays on Tudor and Stuart Literature and Culture (Chicago, 1988) 347-74; Helgerson, Forms of Nationhood, 125-7.

62 The Dramatic Works of Thomas Dekker, 2.301.

63 Ibid, 2.254

64 Ibid, 2.257.

65 Ibid, 2.266.

66 Ibid, 2.268, 269.

67 Ibid, 2.271.

68 Ibid, 2.284.

69 Ibid, 2.303.

70 Important to my thinking about Dekker and his text's adroit control and competitiveness is James Mardock's attention to Dekker's sophisticated authorial and interpretive moves, comparable with though different from Jonson's; see Mardock, Our Scene is London, 38-44.

71 Wall, The Imprint of Gender, 124.

72 Ibid, 162.

73 Butler, 'The King's Entertainment', 1.

74 Harrison, The Arch's of Triumph, 1.

75 Ibid.

76 See Blayney, 'The Publication of Playbooks', 407.

77 Weiss, 'Casting Compositors', 208.

78 Loewenstein, Author's Due, 95.

79 Bergeron, Practicing Renaissance Scholarship, 175.

80 Ibid, 184.

81 Harrison, The Arch's of Triumph, title-page.

82 Loewenstein, Author's Due, 95. 
83 Ibid.

84 Harrison, The Arch's of Triumph, 16.

85 Bergeron, Practicing Renaissance Scholarship, 147, 149.

86 Butler, 'The King's Entertainment', 1.

87 For commentary on the entry as a 'composite text' that is 'pulling in different directions', especially with consideration of Dugdale, see Malcolm Smuts (ed.), 'The Whole Royal and Magnificent Entertainment', Thomas Middleton: The Collected Works, 223.

88 Blayney, 'The Publication of Playbooks', 405.

89 Weiss, 'Casting Compositors', 202.

90 Ibid, 205.

91 Dugdale, The Time Triumphant, 4.

92 Bergeron, Practicing Renaissance Scholarship, 157, 156.

93 Dugdale, The Time Triumphant.

94 Bergeron, Practicing Renaissance Scholarship, 160.

95 Dugdale, The Time Triumphant.

96 Bergeron, Practicing Renaissance Scholarship, 157.

97 Dugdale, The Time Triumphant, 3, 5.

98 Ibid, 6 .

99 This capacious and less orderly picture created is especially significant given the requisite univocality of theatrical rituals like the entry. Writes Angela Stock, 'Unlike stage plays, rituals and ceremonies are not open to interpretation, they have to mean the same thing to everybody involved - now, and in the past and in future'; see Angela Stock, "Something done in honour of the city": Ritual, Theatre and Satire in Jacobean Civic Pageantry', Dieter Miehl, Angela Stock and Anne-Julia Zwierlein (eds), Plotting Early Modern London: New Essays on Jacobean City Comedy (New York, 2007), 135.

100 Dillon, Language of Space, 21.

101 Wall, Imprint of Gender, 114, 126.

102 Ibid, 50. 
